\title{
All green, but equal? Morphological traits and ecological implications on spores of three species of mosses in the Brazilian Atlantic forest
}

\author{
ADAÍSES S. MACIEL-SILVA ${ }^{1,2}$, FLÁVIA C.L. DA SILVA ${ }^{3}$ \\ and IVANY F.M. VÁLIO ${ }^{1}$ \\ ${ }^{1}$ Departamento de Biologia Vegetal, Instituto de Biologia, \\ Universidade Estadual de Campinas/UNICAMP, Caixa Postal 6109, 13083-970 Campinas, SP, Brasil \\ ${ }^{2}$ Departamento de Botânica, Instituto de Ciências Biológicas, \\ Universidade Federal de Minas Gerais/UFMG, Caixa Postal 486, 31270-901 Belo Horizonte, MG, Brasil \\ ${ }^{3}$ Departamento de Biologia, Área de Ensino das Ciências Biológicas, \\ Universidade Federal Rural de Pernambuco/UFRPE, Dois Irmãos, 52171-900 Recife, PE, Brasil
}

Manuscript received on April 15, 2013; accepted for publication on October 14, 2013

\begin{abstract}
Spores of the tropical mosses Pyrrhobryum spiniforme, Neckeropsis undulata and N. disticha were characterized regarding size, number per capsule and viability. Chemical substances were analyzed for $P$. spiniforme and $N$. undulata spores. Length of sporophyte seta (spore dispersal ability) was analyzed for P. spiniforme. Four to six colonies per species in each site (lowland and highland areas of an Atlantic Forest; Serra do Mar State Park, Brazil) were visited for the collection of capsules (2008-2009). Neckeropsis undulata in the highland area produced the largest spores (ca. $19 \mu \mathrm{m})$ with the highest viability. The smallest spores were found in $N$. disticha in the lowland (ca. $13 \mu \mathrm{m}$ ). Pyrrhobryum spiniforme produced more spores per capsule in the highland (ca. 150,000) than in lowland (ca. 40,000); longer sporophytic setae in the lowland (ca. $64 \mathrm{~mm}$ ) than in the highland (ca. $43 \mathrm{~mm}$ ); and similar sized spores in both areas (ca. $16 \mu \mathrm{m}$ ). Spores of $N$. undulata and $P$. spiniforme contained lipids and proteins in the cytoplasm, and acid/neutral lipids and pectins in the wall. Lipid bodies were larger in N. undulata than in P. spiniforme. No starch was recorded for spores. Pyrrhobryum spiniforme in the highland area, different from lowland, was characterized by low reproductive effort, but presented many spores per capsule.
\end{abstract}

Key words: bryophytes, histochemistry, life histories, spore size, spore production, tropical rain forest.

\section{INTRODUCTION}

It is known that green spores of ferns and bryophytes, compared to non-green spores in these plants, tend to lose viability over a short period of time (e.g. within a single day to a few months; Lloyd and Klekowski Jr 1970, Pence 2000, Wiklund and Rydin 2004,

Correspondence to: Adaíses Simone Maciel da Silva E-mail: adaisesmaciel@hotmail.com / adaises.maciel@gmail.com
Maciel da Silva et al. 2009). Green spores generally germinate fast and are frequently associated to taxa with a life program adapted to moist and shaded habitats in temperate and tropical sites (Lloyd and Klekowski Jr 1970). Although species with green spores are generally associated to moist habitats, the evolutionary history of closely related species having green spores and inhabiting similar places must be considered (Sundue et al. 2011). In addition, at least 
for ferns, green spores are apparently more common than presently recorded in literature (Sundue et al. 2011 and references therein), since chlorophyll is hidden by a thick and dark spore wall (Mogensen 1983, Sundue et al. 2011).

Among bryophytes, the majority of species have green spores (Mogensen 1983). Green spores, different from non-green ones, are rich in chlorophyll and starch, but poor in high-longevity storage substances such as lipids (Stetler and DeMaggio 1976, Valanne et al. 1976, Olesen and Mogensen 1978). After maturation, green spores have well developed chloroplasts and are metabolically ready to grow in a few hours under suitable conditions (Paolillo and Jagels 1969). Conversely, non-green spores (yellow, brown or black) need more time to break down storage reserves, develop chloroplasts and germinate into a protonema (Mogensen 1983, Glime 2007a, Sundue et al. 2011).

Regarding bryophytes, relationships among life-history traits such as the number and size of spores may be represented by some plants producing many small spores per sporangium $v s$. plants producing only a few large ones (During 1979, Hedderson and Longton 2008). Relationships between spore size and capsule size are recorded for some mosses, where large capsules have small spores and small capsules have large spores (Egunyomi 1978, Sundberg and Rydin 1998). Sundberg (2005) recorded that the success of spore dispersal increased with the increase in capsule size and decrease in spore size. Since large spores, compared to small ones in the same taxa, generally have many storage reserves, Glime (2007a) suggested that larger spores could improve germination rates through energy storage in the long-term. Large spores are also recorded as having higher desiccation tolerance, but lower germination and protonemal growth rates than small ones (Löbel and Rydin 2010).

Intraspecific variation in life history traits of bryophyte species is not uncommon. Hassel et al.
(2005) detected lowland female plants growing faster and producing spores a year earlier than mountain females in Pogonatum dentatum. Shaw (1990) observed large variations among plants from a single genet in Funaria hygrometrica, mostly regarding gametophyte morphology, germination percentages, gametophytic growth and tolerance to copper. The author suggested that microenvironmental variation within the greenhouse pots could be a cause for this variation. Shaw and Beer (1999) recorded a population of Ceratodon purpureus growing on the asphalt of a driveway, presenting shorter juvenile stage, faster antheridia, higher reproductive output and greater biomass accumulation in comparison to plants in a population on soil in an abandoned gravel pit.

In some of our previous studies (MacielSilva and Valio 2011, Maciel-Silva et al. 2012a, b), investigating bryophyte communities in two different sites of a Brazilian Atlantic forest, we observed substantial level of variation, mostly in relation to spores, among populations of epiphyte and epixylic mosses living in the understory of the two forest sites (highland and lowland). Since natural history data for tropical bryophytes are still scarce, sometimes precluding deeper studies in ecology of these plants, we believe that our study will add knowledge to the biology of tropical bryophytes.

Our main goal in this study is to characterize spores in three tropical mosses, Pyrrhobryum spiniforme, Neckeropsis undulata and $N$. disticha, with respect to 1) size; 2) number produced per capsule; and 3) viability. We also characterize, in $P$. spiniforme and $N$. undulata, 4) chemical substances of spores, with comparisons to other bryophyte species. Beyond these spore traits, the length of sporophyte seta (an indicative of spore dispersal ability) is analyzed for one species, $P$. spiniforme, in the two study sites. We record variations in life history traits and suggest ecological implications of these traits for the life history strategies of the species. 


\section{MATERIALS AND METHODS}

\section{STUDY SITES}

Study sites represented two sites in the Atlantic Ombrophilous Dense Forest (Veloso et al. 1991), a Brazilian tropical rain forest, in the "Núcleo Picinguaba" $\left(23^{\circ} 31^{\prime}-23^{\circ} 34^{\prime} \mathrm{S}\right.$ and $45^{\circ} 02^{\prime}-45^{\circ} 05^{\prime}$ $\mathrm{W})$ and in the "Núcleo Santa Virgínia" $\left(23^{\circ} 17^{\prime}-23^{\circ}\right.$ $24^{\prime} \mathrm{S}$ and $45^{\circ} 03^{\prime}-45^{\circ} 11^{\prime} \mathrm{W}$ ) of the Serra do Mar State Park - State of São Paulo, Brazil. The two forest sites were: a low-altitude forest (Restinga forest at sea level, hereafter called lowland area) and a high-altitude forest (Montane forest at ca. 1,000 $\mathrm{m}$ a.s.l., hereafter called highland area) (for details see Alves et al. 2010, Maciel-Silva et al. 2012a), located ca. $35 \mathrm{~km}$ apart, and characterized by differences in soil nutrients, total biomass, disturbance frequency, and mean temperatures. The lowland area had the lowest numbers of soil nutrients and total biomass, the highest mean temperatures $\left(12^{\circ} \mathrm{C}\right.$ and $32^{\circ} \mathrm{C}$ in the winter and summer, respectively, vs. $4^{\circ} \mathrm{C}$ and $27^{\circ} \mathrm{C}$ in highland area), and was periodically flooded (Alves et al. 2010, Maciel-Silva et al. 2012a).

\section{StUdy Species AND SAMPLING}

We studied three species of mosses: Neckeropsis undulata (Hedw.) Reich. (Neckeraceae) - a Neotropical species commonly found on branches and trunks of trees from the wet lowland to the lower highland forest (sea level $-1,800 \mathrm{~m}$ ); synoicous/ autoicous breeding system; capsules ca. $1.5 \mathrm{~mm}$; classified as pleurocarpous due to the perichaetial position; and with life form pendant (La FargeEngland 1996, Buck 1998, Gradstein et al. 2001, Maciel-Silva and Válio 2011). This species was found on substrates with $\mathrm{pH}$ varying from 4.5 to 6.1 (A.S. Maciel-Silva, unpublished data). Neckeropsis disticha (Hedw.) Kindb. (Neckeraceae) - a Neotropical species found on branches and trunks of trees in the wet lowland forest, but not reaching the lower highland forest (sea level - 1,000 $(1,400) \mathrm{m})$.
This species has autoicous breeding system, capsules ca. $1-1.5 \mathrm{~mm}$, is pleurocarpous and pendant ( $\mathrm{La}$ Farge-England 1996, Buck 1998, Gradstein et al. 2001, Maciel-Silva and Válio 2011). It was found on substrates with $\mathrm{pH}$ from 5.3 to 5.6 (A.S. MacielSilva, unpublished data). Pyrrhobryum spiniforme (Hedw.) Mitt. (Rhizogoniaceae) - Pantropical species frequently associated to decaying wood, trunk base of trees, and soil or humus found from the wet lowland to the highland forests (sea level -3,670 $\mathrm{m}$ ); synoicous (autoicous) breeding system, capsules ca. $1.5-3 \mathrm{~mm}$, cladocarpous and forming tall turf (La Farge-England 1996, Gradstein et al. 2001, Maciel-Silva and Válio 2011). Substrates occupied by $P$. spiniforme varied in $\mathrm{pH}$ between 4.4 and 5.9 (A.S. Maciel-Silva, unpublished data).

Each study site had a 1 ha area $\left(10,000 \mathrm{~m}^{2}\right.$, see Maciel-Silva et al. 2012a for details). Colony size in the three species varied from $\sim 100 \mathrm{~cm}^{2}$ to $1,000 \mathrm{~cm}^{2}$. In each site, we selected colonies of the same species at least $5 \mathrm{~m}$ apart. From each colony, a square of at least $9 \mathrm{~cm}^{2}$ containing sporophytes was collected (put in paper bags and carried to the laboratory). Collections were carried out from April 2008 to April 2009, visiting same colonies in each species. Number of colonies visited varied from six to seven per species in each site, but colonies effectively producing sporophytes during the study varied from four to six in each site. Samples were maintained moist under dark conditions, and conducted to laboratory within a few days of being collected. When the samples were not analyzed immediately, the plant material was stored at $10^{\circ} \mathrm{C}$ and in darkness for no more than one week. Samples in each species in the two sites were analyzed under a dissecting microscope to search for sporophytes containing mature and closed capsules (completely expanded capsules with calyptra generally absent).

Since the colonies varied in the production of sporophytes, e.g. colonies of $P$. spiniforme were always found with many sporophytes in both sites, but $N$. disticha and undulata only had a few 
mature sporophytes per colony during our study, we decided to combine sporophytes of different colonies of the same species in each site to reach a reasonable sample. When the number of mature sporophytes found per species in each site was less than three, we did not analyze this data.

\section{ESTIMATING SPORE NUMBER AND SizE}

To estimate the number of spores produced per capsule (i.e. sporangium), we completely macerated each capsule in a distilled water drop $(0.2 \mathrm{~mL})$ using a piece of glass rod on a glass slide and checking under dissecting microscope if all spores were out of capsule. An aliquot of this homogenized mixture of spores and water was collected using a Pasteur pipette and added to a Neubauer counting chamber. Spores were counted in four replicates of $0.0001 \mathrm{~mL}$. We then estimated the spore number in each capsule. Since in this analysis we needed closed and mature capsules, the number of capsules analyzed varied according to the abundance of sporophytes per species in each site. Another aliquot was added between a slide and lip cover, and using a compound microscope and an ocular micrometer we randomly measured the largest diameter of at least 30 fresh spores.

\section{SPORE VIABILITY}

Spore viability was measured as spore germination percentage. For germination essays, mature and closed capsules of the three species ( $P$. spiniforme in the two sites, and $N$. undulata and $N$. disticha in highland and lowland areas, respectively) were sterilized during two $\mathrm{min}$ in $1.5 \%$ sodium hypochlorite, washed three times in distilled water, and left to dry at lab air (Duckett et al. 2004, Maciel da Silva et al. 2009). Three to twelve capsules (replicates) in each species were opened and spores in each capsule were spread on $1 \mathrm{~mL}$ nutrient solution in a transparent microtube. Knop nutrient solution $\left[\mathrm{Ca}\left(\mathrm{NO}_{3}\right)_{2} \mathrm{H}_{2} \mathrm{O}: 0.5 \mathrm{~g} \mathrm{~L}^{-1} ; \mathrm{MgSO}_{4} 2 \mathrm{H}_{2} \mathrm{O}\right.$ :
$0.175 \mathrm{~g} \mathrm{~L}^{-1} ; \mathrm{KH}_{2} \mathrm{PO}_{4}: 0.175 \mathrm{~g} \mathrm{~L}^{-1} ; \mathrm{KCl}: 0.06 \mathrm{~g} \mathrm{~L}^{-1}$; $\mathrm{FeCl}$ (3\%): $1 \mathrm{~mL} \mathrm{~L}^{-1}$ ] was used (Nehira 1988). Microtubes were randomly located in a growth room at $18^{\circ} \mathrm{C}$ to $27^{\circ} \mathrm{C}$, for a photoperiod of $12-14 \mathrm{~h}$ (fluorescent lamps were responsible for $12 \mathrm{~h}$ light, but in the summer natural light prolonged this to about $14 \mathrm{~h}$ ), and PAR (photosynthetically active radiation) varying from 40 to $100 \mu \mathrm{mol} \mathrm{m} \mathrm{m}^{-2} \mathrm{~s}^{-1}$. After ten days, an aliquot of solution plus spores/ protonemata was taken in each microtube and used to prepare slides and quantify germination percentage from 100 spores. After this time, no significant improvement in spore germination percentage was observed.

LENGTH OF THE SPOROPHYTE SETA

During field collections, we observed differences in length of sporophyte seta of $P$. spiniforme in the two study sites. In order to identify significant differences, we measured the length of seta (mm) in P. spiniforme sporophytes from the two sites (45 setae in each site), taking measures from the seta foot to the intersection between seta and capsule. We analyzed setae only from sporophytes with completely expanded capsules.

\section{HISTOCHEMICAL CHARACTERIZATION}

Spores of Neckeropsis undulata and Pyrrhobryum spiniforme from the highland and lowland areas were used for histochemical characterization. We were not able to find sufficient mature capsules of $N$. disticha in the two sites to perform these tests on spores. Mature and closed capsules were opened, and fresh spores from different capsules (at least four capsules per species in each site) were added to clean glass slides. We used the following histochemical tests: Neutral Red under ultraviolet light, Sudan Black B and Sudan IV for total lipids; Nile Blue for neutral and acid lipids; Ruthenium Red for pectins and mucilage; Lugol for starch; Xylidine Ponceau and Aniline Blue Black for total proteins; and Ferric Chloride for phenols (Johansen 
1940, Cain 1947, Jensen 1962, Feder and O'Brien 1968). Previously, we conducted several tests varying time and heating conditions, and spores stained for $30 \mathrm{~min}$ at $60^{\circ} \mathrm{C}$ showed the best results. Fresh and not stained spores were simultaneously analyzed under white, polarized and ultraviolet light. To characterize spores in relation to chemical substances, we analyzed spores submitted to histochemical tests under a compound microscope. Pictures were taken, and stained spores were compared to the expected color for each specific test, as well as to non-stained fresh spores.

\section{DATA ANALYZES}

We performed descriptive statistics to characterize spore size in each species and site. Histograms were prepared to assess the distribution frequencies, maximum and minimum values of spore size (largest diameter). We used Kruskal-Wallis tests and multiple comparisons of mean ranks to detect significant differences in mean values of: "spore size" (we used mean values of spore size in each capsule); "spore number per capsule"; and "spore germination" among different species and populations of the same species in different sites. A Student t-test compared the mean seta length of Pyrrhobryum spiniforme between lowland and highland areas. We used Statistica 8.0 (StatSoft) to perform all analyses.

\section{RESULTS}

SPORE Size, Number AND GERMINATION, AND LENGTH OF SPOROPHYTE SETA

Comparing populations of the same species between sites, we noted that spore size in Pyrrhobryum spiniforme (Figure 1A - B) and Neckeropsis disticha (Figure 1C - D) did not vary between highland and lowland areas, whilst Neckeropsis undulata (Figure 1E - F) in highland area produced spores slightly larger than those in lowland area. Among the three species, Neckeropsis undulata (in highland area) produced the largest spores (ca. $19 \mu \mathrm{m}$ ), and $N$. disticha (in lowland area) had the smallest spores found in our study (ca. $13 \mu \mathrm{m}$ ) (Table I, KruskalWallis test: $\mathrm{H}=41.28 ; \mathrm{P}<0.001 ; \mathrm{df}=5 ; \mathrm{N}=58$ capsules). Pyrrhobryum spiniforme in the highland area produced more spores per capsule (ca. 150,000) when compared to $P$. spiniforme in the lowland area (ca. 40,000). In the highland area, N. undulata and $N$. disticha produced similar numbers of spores per capsule (Table I, Kruskal-Wallis test: $\mathrm{H}=20.32$; $\mathrm{P}<0.001 ; \mathrm{df}=3, \mathrm{~N}=37$ capsules).

Neckeropsis undulata in the highland area, when compared to P. spiniforme in the two sites and $N$. disticha in the lowland area, had many more spores able to germinate (ca. 90\%). No difference in spore germination was detected for $P$. spiniforme between the two study sites (Table I, Kruskal-Wallis test: $\mathrm{H}=19.08 ; \mathrm{P}<0.001 ; \mathrm{df}=3 ; \mathrm{N}=38$ capsules).

Pyrrhobryum spiniforme in the lowland area had the tallest sporophytic setae (mean $\pm \mathrm{sd}=$ $64.58 \mathrm{~mm} \pm 9.45 \mathrm{~mm}$ ) in comparison to plants in the highland $(43.31 \mathrm{~mm} \pm 7.51 \mathrm{~mm}$; Student t-test: $\mathrm{t}=-14.07 ; \mathrm{P}<0.001 ; \mathrm{df}=124 ; \mathrm{N}=70$ setae).

\section{HISTOCHEMICAL CHARACTERIZATION}

Since no relevant differences associated to spore staining by histochemical tests were observed between populations of the same species inhabiting different sites (lowland and highland areas), we decided to describe histochemical results for each species irrespective of the origin site (for details between sites see Table II). However, when necessary, we present a few contrasting results.

Some bodies into the spore were yellowish and refringent, suggesting presence of oils or lipids. However, since it is not possible to ensure this without specific histochemical tests to detect lipids, we utilized the following descriptions hereafter: "oil-like bodies" when no histochemical technique was applied and "lipid bodies" when these structures positively reacted to specific tests for lipids.

Fresh spores of $P$. spiniforme had numerous chloroplasts and no conspicuous oil-like bodies 

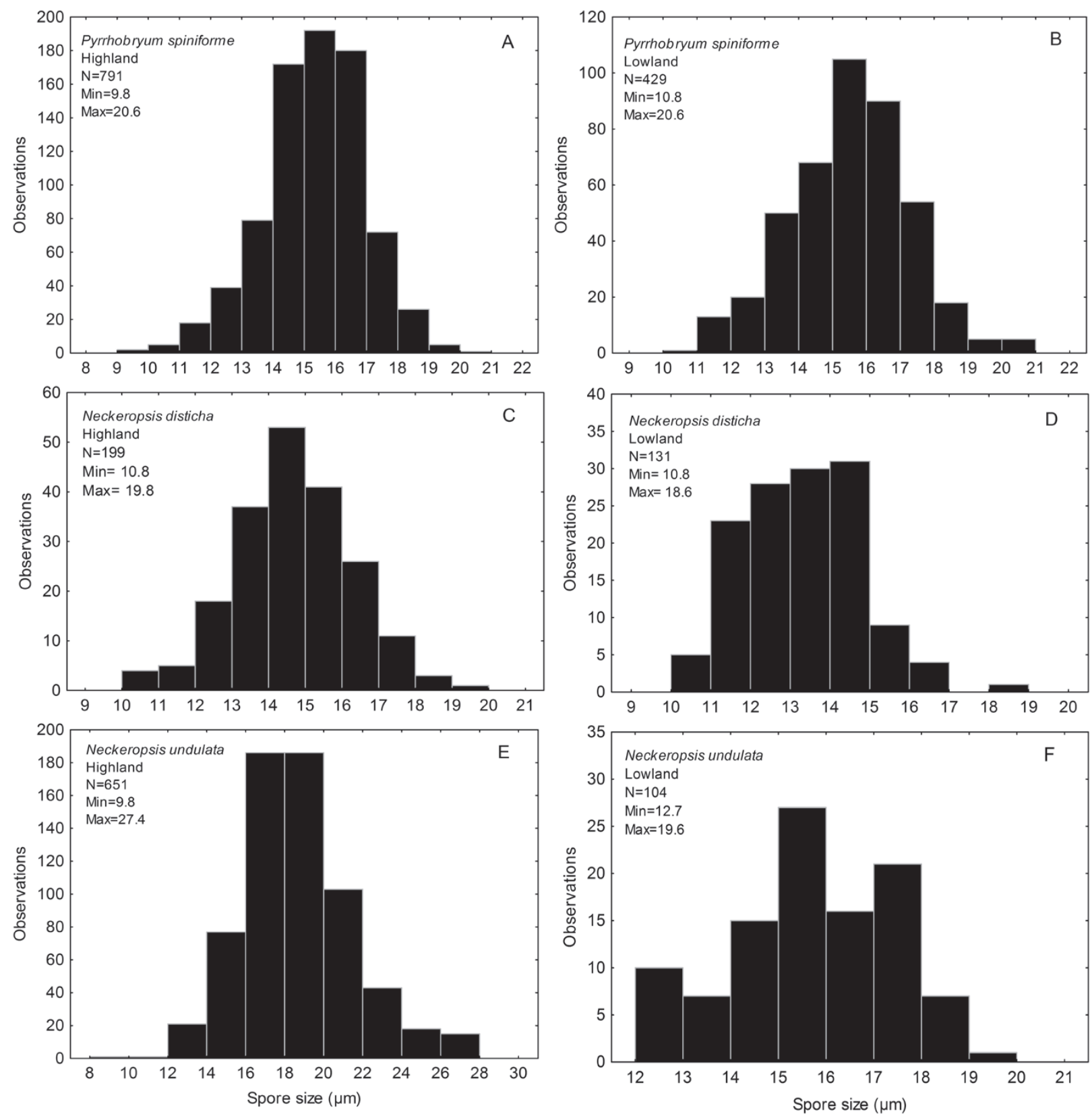

Figure 1 -A-F. Frequency histograms, minimum and maximum values of spore size in the tropical mosses Pyrrhobryum spiniforme, Neckeropsis undulata and N. disticha in Brazilian Atlantic forest sites. A-B. Pyrrhobryum spiniforme, C-D. Neckeropsis disticha, and E-F. Neckeropsis undulata, in highland and lowland areas, respectively.

(Figure 2A, 2K); under UV light, chloroplasts fluoresced in red, whilst oil-like bodies fluoresced in yellow (Figure 2C, 2M). Starch grains were not found under polarized light (Figure 2B, $2 \mathrm{~L})$. Spores reacted positively for total, and for neutral and acid lipids (Table II): spore cytoplasm stained in bright yellow with Neutral
Red under UV (Figure 2D-E, 2N-O; note that positive reaction was only observed for lowland spores); spore cytoplasm stained in black blue with Sudan Black B (Figure 2G, 2Q); and some spherules and matrix material stained in red with Sudan IV (Figure 2H, 2R); and spore wall and cytoplasm stained in blue with Nile Blue (Figure 
TABLE I

Mean \pm standard deviation of spore size, number per capsule, and germination, as well as minimum and maximum values of spore number in the tropical mosses Pyrrhobryum spiniforme, Neckeropsis undulata and $N$. disticha in Brazilian Atlantic forest sites.

Different letters indicate significant differences by multiple comparisons of mean ranks. Numbers in parentheses are number of capsules used in each analysis (N).

\begin{tabular}{|c|c|c|c|c|c|c|}
\hline \multirow[b]{2}{*}{ Measurements } & \multicolumn{3}{|c|}{ Highland } & \multicolumn{3}{|c|}{ Lowland } \\
\hline & P. spiniforme & N. disticha & N. undulata & P. spiniforme & N. disticha & N. undulata \\
\hline $\begin{array}{c}\text { Mean spore size } \\
\pm \text { sd }\end{array}$ & $\begin{array}{c}15.60 \\
\pm 0.57 \mathrm{~b}(15)\end{array}$ & $\begin{array}{c}14.97 \\
\pm 1.00 \mathrm{~b}(6)\end{array}$ & $\begin{array}{c}19.06 \\
\pm 1.87 \mathrm{a}(18)\end{array}$ & $\begin{array}{c}15.76 \\
\pm 1.03 \mathrm{~b}(12)\end{array}$ & $\begin{array}{c}13.53 \\
\pm 0.47 \mathrm{~b}(4)\end{array}$ & $\begin{array}{c}15.78 \\
\pm 0.97 \mathrm{ab}(3)\end{array}$ \\
\hline $\begin{array}{c}\text { Mean spore } \\
\text { number }\end{array}$ & $151,733.3 \mathrm{a}(10)$ & $60,000.0 \mathrm{ab}(5)$ & $62,460.4 \mathrm{ab}(8)$ & $38,708.3 \mathrm{~b}(14)$ & n.a. & n.a. \\
\hline $\begin{array}{l}\text { Min spore } \\
\text { number }\end{array}$ & $61,833.3$ & $40,375.0$ & $38,000.0$ & $9,500.0$ & n.a. & n.a. \\
\hline $\begin{array}{l}\text { Max spore } \\
\text { number }\end{array}$ & $241,000.0$ & $118,125.0$ & $109,875.0$ & $92,666.7$ & n.a. & n.a. \\
\hline $\begin{array}{c}\text { Mean } \\
\text { germination }(\%)\end{array}$ & $\begin{array}{c}60.88 \\
\pm 22.44 \mathrm{~b}(9)\end{array}$ & n.a. & $\begin{array}{c}90.09 \\
\pm 6.97 \mathrm{a}(9)\end{array}$ & $\begin{array}{c}66.98 \\
\pm 18.11 \mathrm{~b}(12)\end{array}$ & $\begin{array}{c}19.81 \\
\pm 17.07 \mathrm{~b}(3)\end{array}$ & n.a. \\
\hline
\end{tabular}

n.a.: not applicable (see Materials and Methods for details).

TABLE II

Results of histochemical tests applied on spores of two tropical mosses, N. undulata and P. spiniforme, in Brazilian Atlantic forest sites.

\begin{tabular}{|c|c|c|c|c|c|c|c|c|c|}
\hline \multirow[b]{3}{*}{ Substance } & \multirow[b]{3}{*}{ Histochemical test } & \multicolumn{4}{|c|}{ Highland } & \multicolumn{4}{|c|}{ Lowland } \\
\hline & & \multicolumn{2}{|c|}{ P. spiniforme } & \multicolumn{2}{|c|}{ N. undulata } & \multicolumn{2}{|c|}{ P. spiniforme } & \multicolumn{2}{|c|}{ N. undulata } \\
\hline & & $\begin{array}{c}\text { Spore } \\
\text { wall }\end{array}$ & Cytoplasm & $\begin{array}{l}\text { Spore } \\
\text { wall }\end{array}$ & Cytoplasm & $\begin{array}{c}\text { Spore } \\
\text { wall }\end{array}$ & Cytoplasm & $\begin{array}{l}\text { Spore } \\
\text { wall }\end{array}$ & Cytoplasm \\
\hline \multirow[t]{3}{*}{ Total lipids } & Neutral Red under UV & - & - & - & ++ & - & ++ & - & - \\
\hline & Sudan Black B & - & ++ & - & ++ & - & ++ & - & ++ \\
\hline & Sudan IV & - & ++ & n.a & n.a. & - & ++ & - & ++ \\
\hline $\begin{array}{l}\text { Neutral and acid } \\
\text { lipids }\end{array}$ & Nile Blue & ++ & ++ & ++ & ++ & ++ & ++ & ++ & ++ \\
\hline \multicolumn{10}{|l|}{ Carbohydrates } \\
\hline Pectins & Ruthenium Red & + & - & ++ & - & + & - & + & - \\
\hline Starch & Lugol & - & - & - & - & - & - & - & - \\
\hline \multirow[t]{2}{*}{ Total proteins } & Xylidine Ponceau & - & ++ & - & ++ & - & ++ & - & ++ \\
\hline & Aniline Blue Black & n.a. & n.a. & n.a. & n.a. & - & ++ & - & ++ \\
\hline Phenols & Ferric Chloride & - & - & - & - & - & - & - & - \\
\hline
\end{tabular}

++, strong positive reaction; +, slightly positive; -, negative; n.a. not applicable.

2F, 2P). Spore wall of some spores stained with Ruthenium Red as an indicative of pectins (Figure 2I, 2S). Spore cytoplasm stained positively for total proteins with Xylidine Ponceau (Figure 2J, 2T) and Aniline Blue Black (Figure 2U). No positive reaction was observed for spores treated with Ferric Chloride (for phenols) or Lugol (for starch) (Table II).
Fresh spores of Neckeropsis undulata were generally green, due to many chloroplasts, and they frequently had oil-like bodies; under UV light chloroplasts fluoresced in red, whilst oil-like bodies in yellow to orange (Figure 3A, 3C). Starch grains were not found, since no structures as "Malta cross" were evidenced under polarized light (Figure 3B). Spores reacted positively for total lipids and for 


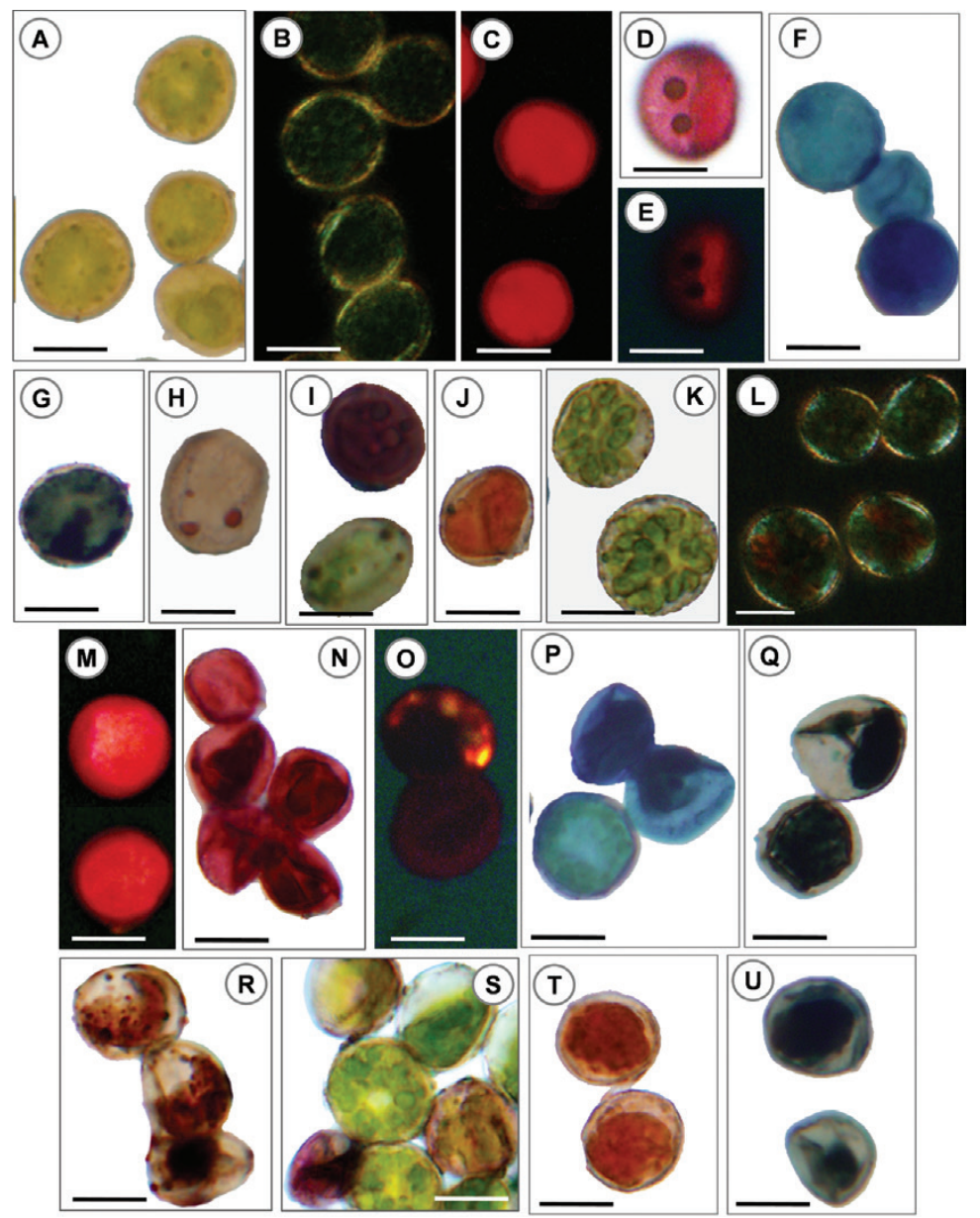

Figure 2 - A-U. Histochemical characterization of Pyrrhobryum spiniforme spores. A - J. Highland spores. K - U. Lowland spores. A - C, K - M. Fresh spores. A, D, F - K, N, P - U. under white light. B, L. polarized light. C, E, M, O. UV light. D, E, N, O. Staining with Neutral Red. F, P. Staining with Nile Blue. G, Q. Staining with Sudan Black B. H, R. Staining with Sudan IV. I, S. Staining with Ruthenium Red. J, T. Staining with Xylidine Ponceau. U. Staining with Aniline Blue Black. Scale Bar: $15 \mu \mathrm{m}$.

neutral and acid lipids (Table II), evidenced by bright yellow exudate staining with Neutral Red under UV (Figure 3D-E); spore cytoplasm stained in black blue with Sudan Black B (Figure 3G, 3L); some bodies stained in red with Sudan IV (Figure $3 \mathrm{M}$ ); spore wall and cytoplasm stained in blue with Nile Blue (Figure 3F, 3K). Spore wall stained with Ruthenium Red as an indicative of pectins (Figure $3 \mathrm{H}, 3 \mathrm{~N})$. Spore cytoplasm stained positively for total proteins with Xylidine Ponceau (Figure 3I, 3O) and Aniline Blue Black (Figure 3P). No positive reaction was observed for spores treated with Lugol (for starch) and Ferric Chloride (for phenols) (Table II).

\section{DISCUSSION}

All Spores ARE GREEN, BUT NOT EQUAL

We found epiphyte (Neckeropsis undulata and $N$. disticha) and epixylic (Pyhhrobryum spiniforme) species with green spores that differed in some degree in terms of size, number per capsule, viability and abundance of storage reserves. All species studied 


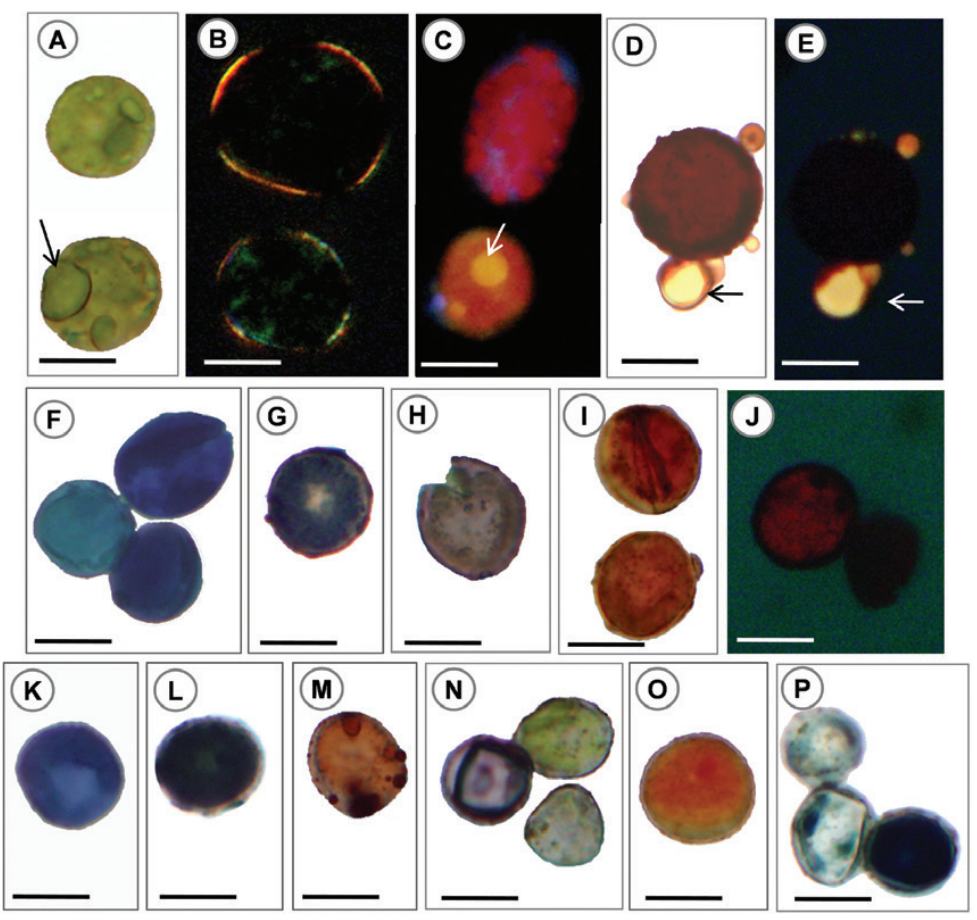

Figure 3 A-P. Histochemical characterization of Neckeropsis undulata spores. A - I. Highland spores. J - P. Lowland spores. A - C. Fresh spores. A, D, F - I, K - P. under white light. B. polarized light. C, E, J. UV light. D, E, J. Staining with Neutral Red. F, K. Staining with Nile Blue. G, L. Staining with Sudan Black B. H, N. Staining with Ruthenium Red. I, O. Staining with Xylidine Ponceau. M. Staining with Sudan IV. P. Staining with Aniline Blue Black. Scale bar: $15 \mu \mathrm{m}$.

here had smaller spores $(<20 \mu \mathrm{m})$ in accordance to "the bryophyte life strategies classification" (During 1992 apud Glime 2007b), with low storage capacity and high dispersal ability. However, even inside these "small-spore" species, we noticed variations in spore traits. The epiphyte $N$. undulata in the highland area had few and larger spores with conspicuous lipid bodies associated to high germination percentage and an expected longer longevity, when compared to many and smaller spores produced by the epixylic $P$. spiniforme in the same site, and few and smaller spores in P. spiniforme in the lowland. Neckeropsis undulata and $N$. disticha in the highland area produced similar numbers of spores that differed in size.

Although green (chlorophyll-containing) spores are generally classified as low-longevity spores due to fast degradation of chlorophyll (Lloyd and
Klekowski Jr 1970, Pence 2000, Wiklund and Rydin 2004, Maciel da Silva et al. 2009), Sundue et al. (2011) have detected a weak sign of chlorophyll, using fluorescence microscopy, in spores up to 110 yrs old for ferns Osmundastrum cinnamomeum and Terpsichore asplenifolia kept in herbarium. This suggests that at least some of these green spores could remain alive, and the same could be expected for bryophyte green spores.

Additionally, green spores may differ among species. Spores like those in N. undulata in our study, with conspicuous lipid reserves, can survive longer than green spores without lipid reserves. Green spores without conspicuous lipid reserves were found in the moss Thamniopsis incurva, and they completely lost the viability within three months of storage at laboratory (Maciel da Silva et al. 2009). 
CHARACTERIZATION OF CHEMICAL SUBSTANCES IN

BRYOPHYTE SPORES

Presence of acid and neutral lipids, beyond pectins in the spore wall of $P$. spiniforme and $N$. undulata agree with data for other bryophytes (Mogensen 1983). Pectins in the intine layer are the main substances - in addition to sporopolenin in the exine layer of spores - responsible for the resistance of spores to desiccation and solar radiation (Mogensen 1983, Glime 2007a, Goffinet et al. 2009).
Substances in the spore cytoplasm of $P$. spiniforme and $N$. undulata are very similar to substances found in green spores of other species (see Table III), being mostly lipids (more conspicuous in N. undulata than in P. spiniforme) and proteins. In our study no clear evidence of starch into chloroplasts was observed, differing from the common occurrence of starch grains in green spores of bryophyte species. The majority of studies (Table III) use spores previously hydrated

TABLE III

Spore color, size $(\mu \mathrm{m})$ and storage reserves in different bryophyte species. Spore color and size information was complementarily searched at http://www.efloras.org/index.aspx

\begin{tabular}{|c|c|c|c|c|c|c|}
\hline \multirow{2}{*}{ Species } & \multicolumn{2}{|c|}{ Spore traits } & \multicolumn{3}{|c|}{ Storage reserves } & \multirow[t]{2}{*}{ Reference } \\
\hline & Color & $\begin{array}{l}\text { Size } \\
(\mu \mathrm{m})\end{array}$ & Lipid & Starch & Protein & \\
\hline $\begin{array}{l}\text { Neckeropsis undulata } \\
\text { (Hedw.) Reichardt }\end{array}$ & Green & $10-27$ & $\begin{array}{l}\text { Lipid bodies in } \\
\text { the cytoplasm } \\
\text { (abundant) }\end{array}$ & Not seen & $\begin{array}{l}\text { Protein in the } \\
\text { cytoplasm }\end{array}$ & In this study \\
\hline $\begin{array}{l}\text { Pyrrhobryum spiniforme } \\
\text { (Hedw.) Mitt. }\end{array}$ & Green & $10-20$ & $\begin{array}{l}\text { Lipid bodies in } \\
\text { the cytoplasm (a } \\
\text { few) }\end{array}$ & Not seen & $\begin{array}{l}\text { Protein in the } \\
\text { cytoplasm }\end{array}$ & In this study \\
\hline Dawsonia superba Grev. & Green & $5-8$ & $\begin{array}{l}\text { Lipid bodies in } \\
\text { the cytoplasm }\end{array}$ & $\begin{array}{l}\text { Starch grains } \\
\text { in the plastids }\end{array}$ & $\begin{array}{l}\text { Protein } \\
\text { bodies in the } \\
\text { cytoplasm }\end{array}$ & Stetler and DeMaggio 1976 \\
\hline $\begin{array}{l}\text { Dicranum scoparium } \\
\text { Hedw. }\end{array}$ & Green & $16-20$ & $\begin{array}{l}\text { Lipid bodies in } \\
\text { the cytoplasm }\end{array}$ & $\begin{array}{l}\text { Starch grains } \\
\text { in the plastids }\end{array}$ & $\begin{array}{l}\text { Protein } \\
\text { bodies in the } \\
\text { cytoplasm }\end{array}$ & Valanne et al. 1976 \\
\hline $\begin{array}{l}\text { Riccardia pinguis (L.) } \\
\text { Gray = Aneura pinguis } \\
\text { (L.) Dumort. }\end{array}$ & Green & $60-70$ & $\begin{array}{l}\text { Lipid bodies in } \\
\text { the cytoplasm }\end{array}$ & $\begin{array}{l}\text { Starch grains } \\
\text { in the plastids }\end{array}$ & No record & Horner et al. 1966 \\
\hline $\begin{array}{l}\text { Polytrichum commune } \\
\text { Hedw. }\end{array}$ & Green & $\begin{array}{l}5-8 \\
(-12)\end{array}$ & $\begin{array}{l}\text { Lipid bodies in } \\
\text { the cytoplasm }\end{array}$ & $\begin{array}{l}\text { Starch grains } \\
\text { in the plastids }\end{array}$ & No record & $\begin{array}{l}\text { Olesen and Mogensen } 1978 \\
\text { (hydrated spores) }\end{array}$ \\
\hline $\begin{array}{l}\text { Macromitrium sulcatum } \\
\text { (Hook.) Brid. }\end{array}$ & Green & No data & $\begin{array}{l}\text { Lipid bodies in } \\
\text { the cytoplasm } \\
\text { (few and small) }\end{array}$ & $\begin{array}{l}\text { Starch grains } \\
\text { in the plastids }\end{array}$ & No record & $\begin{array}{l}\text { Olesen and Mogensen } 1978 \\
\text { (hydrated large spores) }\end{array}$ \\
\hline $\begin{array}{l}\text { Macromitrium sulcatum } \\
\text { (Hook.) Brid. }\end{array}$ & Green & No data & $\begin{array}{l}\text { Lipid bodies in } \\
\text { the cytoplasm } \\
\text { (few and small) }\end{array}$ & $\begin{array}{l}\text { Starch grains } \\
\text { in the plastids } \\
\text { (few plastids) }\end{array}$ & No record & $\begin{array}{l}\text { Olesen and Mogensen } 1978 \\
\text { (hydrated small spores) }\end{array}$ \\
\hline $\begin{array}{l}\text { Amblystegium riparium } \\
\text { (Hedw.) Schimp. }= \\
\text { Leptodictyum riparium } \\
\text { (Hedw.) Warnst. }\end{array}$ & Green & $10-24$ & $\begin{array}{l}\text { Lipid bodies in } \\
\text { the cytoplasm }\end{array}$ & $\begin{array}{l}\text { Starch grains } \\
\text { in the plastids } \\
\text { (few and } \\
\text { small) }\end{array}$ & No record & Brown and Lemmon 1980 \\
\hline $\begin{array}{l}\text { Ceratodon purpureus } \\
\text { (Hedw.) Brid }\end{array}$ & Yellowish & $11-13$ & $\begin{array}{l}\text { Lipid bodies in } \\
\text { the cytoplasm }\end{array}$ & $\begin{array}{l}\text { Starch grains } \\
\text { in the plastids }\end{array}$ & No record & $\begin{array}{l}\text { Olesen and Mogensen } 1978 \\
\text { (hydrated spores) } \\
\text { Valanne } 1966 \text { (dry spores) }\end{array}$ \\
\hline $\begin{array}{l}\text { Ptychomitrium dentatum } \\
\text { (Mitt.) A. Jaeger }\end{array}$ & $\begin{array}{l}\text { Yellowish } \\
\text { green }\end{array}$ & $\begin{array}{l}10-14 \\
(-25)\end{array}$ & $\begin{array}{l}\text { Lipid bodies in } \\
\text { the cytoplasm }\end{array}$ & $\begin{array}{l}\text { Starch grains } \\
\text { in the plastids } \\
\text { (large) }\end{array}$ & No record & Estébanez et al. 2006 \\
\hline
\end{tabular}


TABLE III (continuation)

\begin{tabular}{|c|c|c|c|c|c|c|}
\hline \multirow[b]{2}{*}{ Species } & \multicolumn{2}{|c|}{ Spore traits } & \multicolumn{3}{|c|}{ Storage reserves } & \multirow[t]{2}{*}{ Reference } \\
\hline & Color & $\begin{array}{l}\text { Size } \\
(\mu \mathrm{m})\end{array}$ & Lipid & Starch & Protein & \\
\hline $\begin{array}{l}\text { Ptychomitrium gardneri } \\
\text { Lesq. }\end{array}$ & $\begin{array}{l}\text { Yellowish } \\
\text { green }\end{array}$ & $\begin{array}{l}10-14 \\
(-20)\end{array}$ & $\begin{array}{l}\text { Lipid bodies in } \\
\text { the cytoplasm }\end{array}$ & $\begin{array}{l}\text { Starch grains in } \\
\text { the plastids }\end{array}$ & No record & Estébanez et al. 2006 \\
\hline $\begin{array}{l}\text { Ptychomitrium } \\
\text { linearifolium Reimers } \\
\text { \& Sakurai }\end{array}$ & $\begin{array}{l}\text { Yellowish } \\
\text { green? }\end{array}$ & $7-11$ & $\begin{array}{l}\text { Lipid bodies in } \\
\text { the cytoplasm } \\
\text { (scarce) }\end{array}$ & $\begin{array}{l}\text { Starch grains in } \\
\text { the plastids (few) }\end{array}$ & No record & $\begin{array}{l}\text { Estébanez, Yamagushi } \\
\text { and Degushi } 2006\end{array}$ \\
\hline $\begin{array}{l}\text { Ptychomitrium sinense } \\
\text { (Mitt.) A. Jaeger }\end{array}$ & $\begin{array}{l}\text { Yellowish } \\
\text { green }\end{array}$ & $13-18$ & $\begin{array}{l}\text { Lipid bodies in } \\
\text { the cytoplasm } \\
\text { (abundant) }\end{array}$ & $\begin{array}{l}\text { Starch grains in } \\
\text { the plastids (few) }\end{array}$ & No record & $\begin{array}{l}\text { Estébanez, Yamagushi } \\
\text { and Degushi } 2006\end{array}$ \\
\hline $\begin{array}{l}\text { Ditrichum pallidum } \\
\text { (Hedw.) Hampe }\end{array}$ & Brown & $15-30$ & $\begin{array}{l}\text { Lipid bodies in } \\
\text { the cytoplasm }\end{array}$ & $\begin{array}{l}\text { Starch grains in } \\
\text { the plastids }\end{array}$ & No record & Brown and Lemon 1980 \\
\hline $\begin{array}{l}\text { Funaria hygrometrica } \\
\text { Hedw. }\end{array}$ & Yellowish & $12-21$ & $\begin{array}{l}\text { Lipid bodies in } \\
\text { the cytoplasm }\end{array}$ & $\begin{array}{l}\text { Starch grains in } \\
\text { the plastids }\end{array}$ & No record & $\begin{array}{l}\text { Olesen and Mogensen } \\
1978 \text { (hydrated spores) }\end{array}$ \\
\hline $\begin{array}{l}\text { Funaria hygrometrica } \\
\text { Hedw. }\end{array}$ & Yellowish & $12-21$ & $\begin{array}{l}\text { Lipid bodies in } \\
\text { the cytoplasm } \\
\text { (very abundant) }\end{array}$ & $\begin{array}{c}\text { Starch grains } \\
\text { in the plastids } \\
\text { (sparsely present) }\end{array}$ & $\begin{array}{l}\text { Diffuse } \\
\text { protein } \\
\text { bodies in the } \\
\text { cytoplasm }\end{array}$ & $\begin{array}{l}\text { Monroe } 1968 \\
\text { (dry spores) }\end{array}$ \\
\hline $\begin{array}{l}\text { Funaria hygrometrica } \\
\text { Hedw. }\end{array}$ & Yellowish & $12-21$ & $\begin{array}{l}\text { Lipid bodies in } \\
\text { the cytoplasm } \\
\text { (depleted in part) }\end{array}$ & $\begin{array}{l}\text { Starch grains } \\
\text { in the plastids } \\
\text { (abundant) }\end{array}$ & $\begin{array}{l}\text { Diffuse } \\
\text { protein } \\
\text { bodies in the } \\
\text { cytoplasm }\end{array}$ & $\begin{array}{c}\text { Monroe } 1968 \\
\text { (hydrated spores) }\end{array}$ \\
\hline $\begin{array}{l}\text { Grimmia decipiens } \\
\text { (Schultz) Lindb. }\end{array}$ & Yellowish? & $13-20$ & $\begin{array}{l}\text { Lipid bodies in } \\
\text { the cytoplasm } \\
\text { (abundant) }\end{array}$ & No record & No record & Estébanez et al. 1997 \\
\hline $\begin{array}{l}\text { Grimmia elatior Bruch } \\
\text { ex Bals.-Criv. \& De } \\
\text { Not. }\end{array}$ & Yellowish? & $\begin{array}{l}10-12 \\
(-19)\end{array}$ & $\begin{array}{l}\text { Lipid bodies in } \\
\text { the cytoplasm }\end{array}$ & No record & No record & Estébanez et al. 1997 \\
\hline $\begin{array}{l}\text { Grimmia funalis } \\
\text { (Schwägrichen) Bruch } \\
\text { and Schimper }\end{array}$ & Yellowish? & $15-25$ & $\begin{array}{l}\text { Lipid bodies in } \\
\text { the cytoplasm }\end{array}$ & No record & No record & Estébanez et al. 1997 \\
\hline $\begin{array}{l}\text { Grimmia orbicularis } \\
\text { Bruch }\end{array}$ & Yellowish? & $9-15$ & $\begin{array}{l}\text { Lipid bodies in } \\
\text { the cytoplasm }\end{array}$ & No record & No record & Estébanez et al. 1997 \\
\hline $\begin{array}{l}\text { Grimmia pulvinata } \\
\text { (Hedw.) Sm. }\end{array}$ & Yellowish? & $\begin{array}{l}7-12 \\
(-13)\end{array}$ & $\begin{array}{l}\text { Lipid bodies in } \\
\text { the cytoplasm } \\
\text { (abundant) }\end{array}$ & No record & No record & Estébanez et al. 1997 \\
\hline $\begin{array}{l}\text { Grimmia trichophylla } \\
\text { Grev. }\end{array}$ & Yellowish? & $9-19$ & $\begin{array}{l}\text { Lipid bodies in } \\
\text { the cytoplasm } \\
\text { (abundant) }\end{array}$ & No record & No record & Estébanez et al. 1997 \\
\hline Fissidens limbatus Sull. & Green? & $10-16$ & $\begin{array}{l}\text { Lipid bodies in } \\
\text { the cytoplasm } \\
\text { (abundant) }\end{array}$ & $\begin{array}{l}\text { Starch grains in } \\
\text { the plastids }\end{array}$ & No record & Mueller 1974 \\
\hline
\end{tabular}

for some hours, resulting in the beginning of germination (spore swelling, sensu Valanne 1966) and conversion of other storage substances (e.g. lipids) into starch.

Histochemical studies generally reveal chemical substances in the spores in a qualitative way. So, it is hard to compare green and non-green spores based only on the occurrence of substances (Table III). However, when there is more detailed information (e.g. large lipid bodies vs. scarce lipid bodies) it is possible to emphasize the relevant differences among spores. Yellow spores of Funaria hygrometrica are a good example (Monroe 1968): dry spores have large and abundant lipid bodies and scarce starch grains, and after hydration lipids become depleted and starch abundant. After hydration, non-green spores take longer to develop chloroplasts 
from simple plastids, to mobilize storage reserves and to germinate, when compared to green spores that are able to reach $100 \%$ of photosynthesis within $1 \mathrm{~h}: 30 \mathrm{~min}$ (Paolillo and Jagels 1969).

Protein as storage substances in spores of bryophytes seems to be uncommon, with a few records for the mosses Dawsonia, Dicranum and Funaria (Monroe 1968, Stetler and DeMaggio 1976, Valanne et al. 1976). In these cases, proteins are generally found as protein bodies and associated to lipid bodies of both green and non-green spores, disappearing during germination (Table III). Still, the main spore proteins are associated to chlorophyll in chloroplasts and are not storage substances (Valanee et al. 1976). Since longevity of storage reserves in bryophyte diaspores seems to increase from starch to protein and lipid (Duckett and Renzaglia 1993), we suggest that green spores with conspicuous lipid bodies (e.g. N. undulata) are able to survive longer than green spores having only starch into chloroplasts, but shorter than spores with many lipid bodies as storage substances and no chlorophyll.

ECOLOGICAL IMPLICATIONS FOR PYRRHOBRYUM SPINIFORME

Pyrrhobryum spiniforme uses different strategies in the two study sites, where plants in highland area, in comparison to those in lowland, produce approximately four fold spores per capsule; sporophytic setae are $1.5 \mathrm{x}$ longer in lowland than in highland area; and finally the two populations have similar sizes of spores. Different from Shaw and Beer (1999), in our study sporophytes having long setae do not have many spores (e.g. P. spiniforme in lowland area), and presumably have smaller capsules.

Compared to the lowland, P. spiniforme in the highland area has a high reproductive output (a between-ploidy parameter, see Shaw and Beer 1999), mainly expressed as spores (potential gametophytes) produced per sporophyte. Conversely, a previous study with same populations of $P$. spiniforme detected a low reproductive effort (number of sexual branches per mass) among highland plants when compared to lowland ones (Maciel-Silva et al. 2012b). Moreover, total biomass of plants in P. spiniforme in the highland (mean $45.7 \mathrm{mg}$, min $16.6 \mathrm{mg}$, max $127.8 \mathrm{mg} ; \mathrm{n}=6$ colonies) is lower when compared to plants in the lowland area $(71.1 \mathrm{mg}, 21.6 \mathrm{mg}, 133.4 \mathrm{mg} ; \mathrm{n}=6)$ (A.S. Maciel-Silva, unpublished data).

Variations in life history traits and strategies of $P$. spiniforme are not fixed in the species, and seem to respond according to the environmental conditions in both study sites. Lowland, different from highland area, is a forest exposed to periodical flooding and disturbance, higher temperatures and solar radiation in the understory (Alves et al. 2010, Maciel-Silva et al. 2012a). Moreover, the availability of decaying wood on the forest ground of the lowland (46.8 $\left.\mathrm{Mg} \mathrm{ha}^{-1}\right)$ is fewer than that in the highland (69.5 $\mathrm{Mg} \mathrm{ha}^{-1}$ ) (L. Veiga, unpublished data). Pyrrhobryum spiniforme in the highland area, different from the lowland, was characterized by low reproductive effort, but presented many spores per capsule.

\section{ACKNOWLEDGMENTS}

We thank Nivea D. dos Santos, Nazareth G. Urquiza and Poliana R. Cardoso for help in field work and applying histochemical tests in laboratory. ASM-S was supported by Coordenação de Aperfeiçoamento de Pessoal de Nível Superior (CAPES) and Conselho Nacional de Desenvolvimento Científico e Tecnológico ( $\mathrm{CNPq}$ ) (PhD scholarship). This work was supported by the Fundação de Amparo à Pesquisa do Estado de São Paulo (FAPESP) financial resources, as part of the Thematic Project "Functional Gradient" (FAPESP 03/12595-7) within the BIOTA/FAPESP Program-The Biodiversity Virtual Institute (http://www.biota.org.br).

\section{RESUMO}

Esporos dos musgos tropicais Pyrrhobryum spiniforme, Neckeropsis undulata e $N$. disticha foram caracterizados quanto ao tamanho, número por cápsula e viabilidade. 
Substâncias químicas foram analisadas para $P$. spiniforme e $N$. undulata. O comprimento da seta esporofítica (habilidade de dispersão dos esporos) foi analisado em P. spiniforme. Quatro a seis colônias por espécie em cada localidade de estudo (Floresta de restinga e montana no Parque Estadual da Serra do Mar, São Paulo, Brasil) foram visitadas para coleta de cápsulas (2008 - 2009). Neckeropsis undulata na Floresta montana produziu os maiores esporos (ca. 19 $\mu \mathrm{m})$, com maior viabilidade. Os menores esporos foram encontrados em $N$. disticha na Floresta de restinga (ca. $13 \mu \mathrm{m})$. Pyrrhobryum spiniforme produziu mais esporos por cápsula na Floresta montana (ca. 150.000) do que na Floresta de restinga (ca. 40.000); setas esporofíticas mais longas na Floresta de restinga (ca. $64 \mathrm{~mm}$ ) do que na montana (ca. $43 \mathrm{~mm}$ ); e esporos de tamanho similar em ambas localidades (ca. $16 \mu \mathrm{m}$ ). Esporos de $N$. undulata e P. spiniforme contiveram lipídios e proteínas no citoplasma, e lipídios ácidos/neutros e pectinas na parede. Corpúsculos lipídicos foram maiores em N. undulata do que em P. spiniforme. Amido não foi registrado nos esporos. Pyrrhobryum spiniforme na Floresta montana, diferente da Floresta de restinga, caracterizou-se pelo baixo esforço reprodutivo, mas muitos esporos por cápsula.

Palavras-chave: briófitas, histoquímica, histórias de vida, tamanho do esporo, produção de esporos, florestas pluviais tropicais.

\section{REFERENCES}

Alves lF, Vieira SA, Scaranello ma, Camargo PB, SANTOS FAM, JOLY CA AND MARTINELli LA. 2010. Forest structure and live aboveground variation along an elevational gradient of tropical Atlantic moist forest (Brazil). Forest Ecol Management 260: 679-691.

BROWN RC AND LEMMON BE. 1980. Ultrastructure of sporogenesis in a moss, Ditrichum pallidum. III. Spore wall formation. Am J Bot 67: 918-934.

BUCK WR. 1998. Pleurocarpous mosses of the West Indies. Mem New York Botan G 82: 1-400.

CAIN AJ. 1947. The use of Nile Blue in the examination of lipoids. Q J Microsc Sci 88: 383-392.

Duckett JG, Burch J, Fletcher PW, MAtcham HW, Read DJ, RUSSELL A AND PRESSEL S. 2004. In vitro cultivation of bryophytes: a review of practicalities, problems, progress and promise. J Bryol 26: 3-20.
DuCKett JG AND RENZAgLIA KS. 1993. The reproductive biology of the liverwort Blasia pusilla L. J Bryol 17: 541-552.

DURING HJ. 1979. Life strategies of bryophytes: a preliminary review. Lindbergia 5: 2-18.

EGUNYOMI A. 1978. Studies on polysety in the Nigerian moss flora with special reference to Octoblepharum albidum and Calymperes subdecolorans. Bryologist 81: 94-99.

EstéBAnez B, ALFAYATE C AND Ron E. 1997. Observations on spore ultrastructure in six species of Grimmia (Bryopsida). Grana 36: 347-357.

EstéBAnez B, YAMAguchi T AND DEguchi H. 2006. Ultrastructure of the spore in four Japanese species of Ptychomitrium Fürnr. (Musci). Grana 45: 61-70.

FEDER N AND O'BRIEN TP. 1968. Plant microtechnique: some principles and new methods. Am J Bot 55: 123-142.

GLIME J. 2007a. Ecophysiology of development: spore germination. In: Bryophyte Ecology. Volume 1. Physiological Ecology. Ebook sponsored by Michigan Technological University and the International Association of Bryologists. Retrieved December 05, 2012. <http:www. bryoecol.mtu.edu>

GLIME J. 2007b. Adaptive strategies: life cycles. In: Bryophyte Ecology. Volume 1. Physiological Ecology. Ebook sponsored by Michigan Technological University and the International Association of Bryologists. Retrieved December 14, 2013. <http:www.bryoecol.mtu.edu>

Goffinet B, BUCK WR AND SHAW AJ. 2009. Morphology, anatomy, and classification of the Bryophyta. In: GOFFINET B AND SHAW AJ (Eds), Bryophyte Biology, Cambridge: Cambridge University Press, Cambridge, UK, p. 55-138.

GradsteIn SR, ChURChILl SP AND ALLEN NS. 2001. Guide to the bryophytes of Tropical America. Mem New York Botan G 86: 1-577.

HASSEL K, BÅRD P AND SÖDERSTRÖM L. 2005. Changes in lifehistory traits in an expanding moss species: phenotypic plasticity or genetic differentiation? A reciprocal transplantation experiment with Pogonatum dentatum. Ecography 28: 71-80.

HEDDERSON TA AND LONGTON RE. 2008. Local adaptation in moss life histories: population-level variation and a reciprocal transplant experiment. J Bryol 30: 1-11.

HoRNER JR HT, LERSTEN NR AND BOWEN CC. 1966. Spore development in the liverwort Riccardia pinguis. Am J Bot 53: $1048-1064$.

JENSEN WA. 1962. Botanical histochemistry. London: W.H. Freeman \& Co., $408 \mathrm{p}$.

JOHANSEN DA. 1940. Plant microtechnique. New York: Mc Graw Hill, 523 p.

LA FARGE-ENGLAND C. 1996. Growth form, branching pattern, and perichaetial position in mosses: cladocarpy and pleurocarpy redefined. The Bryologist 99: 170-186.

LLOYD RM AND KLEKOWSKI JR EJ. 1970. Spore germination and viability in pteridophyta: evolutionary significance of chlorophyllous spores. Biotropica 2: 129-137. 
LÖBEL S AND RYDIN H. 2010. Trade-offs and habitat constraints in the establishment of epiphytic bryophytes. Func Ecol 24: 887-897.

Maciel da Silva AS, PôRTo KC AND Simabukuro EA. 2009. Effect of light and water availability on spore germination and protonemal growth of the Neotropical moss Thamniopsis incurva (Pilotrichaceae). Cryptogam Bryol 30: 243-257.

MACIEL-SILVA AS AND VÁlio IFM. 2011. Reproductive phenology of bryophytes in tropical rain forests: the sexes never sleep. Bryologist 114: 708-719.

MACIEL-SILVA AS, VÁLIO IFM AND RYDIN H. 2012a. Diaspore bank of bryophytes in tropical rain forests: the importance of breeding system, phylum and microhabitat. Oecologia 168: 321-333.

MACIEL-SILVA AS, VÁLIO IFM AND RYDIN H. 2012b. Altitude affects the reproductive performance in monoicous and dioicous bryophytes: examples from a Brazilian Atlantic rainforest. AoB Plants: 1-14.

Mogensen GS. 1983. The spore. In: Schuster RM (Ed), New Manual of Bryology. Nichinan: The Hattori Botanical Laboratory, Nichinan, Japan. p 325-342.

MONROE JH. 1968. Light- and electron-microscopic observations on spore germination in Funaria hygrometrica. Bot Gaz 129: $247-258$.

MUELLER DMJ. 1974. Spore wall formation and chloroplast development during sporogenesis in the moss Fissidens limbatus. Am J Bot 61: 525-534.

NEHIRA K. 1988. Germination and protonema. In: GLIME JM (Ed), Methods in Bryology. Nichinan: Hattori Botanical Laboratory, Nichinan, Japan, p. 113-117.

Olesen P AND MOGENSEN GS. 1978. Ultrastructure, histochemistry and notes on germination stages of spores in selected mosses. Bryologist 81: 493-516.

PAOLILlO JR DJ AND JAGELS RH. 1969. Photosynthesis and respiration in germinating spores of Polytrichum. Bryologist 72: 444-451.
PENCE VC. 2000. Survival of chlorophyllous and nonchlorophyllous fern spores through exposure to liquid nitrogen. Am Fern J 90: 119-126.

SHAW J. 1990. Intraclonal variation in morphology, growth rate, and copper tolerance in the moss Funaria hygrometrica. Evolution 44: 441-447.

SHAW J AND BEER SC. 1999. Life history variation in gametophyte populations of the moss Ceratodon purpureus (Ditrichaceae). Am J Bot 86: 512-521.

StetLer DA AND DEMAGgIO AE. 1976. Ultrastructural characteristics of spore germination in the moss Dawsonia suiperba. Am J Bot 63: 438-442.

SunDBERG S. 2005. Larger capsules enhance short-range spore dispersal in Sphagnum, but what happens further away? Oikos 108: 115-124.

SUNDBERG S AND RYDIN H. 1998. Spore number in Sphagnum and its dependence on spore and capsule size. J Bryol 20: 1-16.

Sundue M, VASCO A AND MoRAn RC. 2011. Cryptochlorophyllous spores in ferns: nongreen spores that contain chlorophyll. Int J Plant Sci 172: 1110-1119.

VALANNE N. 1966. The germination phases of mosses spores and their control by light. Ann Bot Fenn 3: 1-60.

VALANNE N, TOIVONEN S AND SAARINEN R. 1976. Ultrastructural changes in germinating Dicranuim scopariuim: a moss containing protein storage material. Bryologist 79: $188-198$

Veloso HP, RANGel Filho ALR AND Lima JCA. 1991. Classificação da Vegetação Brasileira, Adaptada a um Sistema Universal. IBGE, Departamento de Recursos Naturais e Estudos Ambientais, Rio de Janeiro, Brasil, p. 124.

WIKLUND K AND RYDIN H. 2004. Ecophysiological constraints on spore establishment in bryophytes. Func Ecol 18: 907-913. 